


\title{
International experience in preventing intentional homicide by criminal police units
}

\author{
DOI: https://doi.org/10.46398/cuestpol.3969.39
}

\author{
Yevhen Khyzhniak * \\ Volodymyr Kapustnyk ** \\ Tetiana Batrachenko *** \\ Iryna Chuprikova $* * * *$ \\ Artem Kryshchenko $* * * * *$
}

\begin{abstract}
The objective of the article is to analyze the international experience of the operational and investigative prevention of intentional homicides by criminal police units, as well as the legislation that provides for the development of an effective system for the prevention of intentional homicides in Ukraine. The subject of the investigation is the foreign experience of operational prevention and the search for intentional homicides by criminal police units. The research methodology includes general and specific methods of legal science: dialectic, scientific abstraction, methods of systems analysis, formal and dogmatic, systemic, and structural, historical, and comparative, logical. Various intentional homicide prevention programs are considered, which are currently operating in different countries of the world. It analyzes the positive international experience of operational and investigative prevention of intentional homicides, which can become the basis for the development of the relevant legislation of Ukraine in this area. It is concluded that the conduct of a comparative analysis of the prevention of intentional homicides and various countries is the basis for the development of the most promising areas to improve domestic legislation in this area.
\end{abstract}

* Ph.D. in Law, Associate Professor, Associate Professor of the Department of Criminalistics of the National University "Odessa Law Academy". ORCID ID: https://orcid.org/oooo-ooo1-8263-0353. Email: Khyzhniak@onua.edu.ua

** Doctor of Law. Assistant Professor of the Department of Forensic Medicine, Medical Law named after honored prof. M.S. Bocarius of Kharkiv National Medical University. ORCID ID: https://orcid. org/oooo-0003-0733-4233. Email: kapustnykv@gmail.com

*** Ph.D. in Law, Associate Professor of the Department of Law Enforcement and Criminal and Legal disciplines of the University of Customs and Finance. ORCID ID: https://orcid.org/0000-0002-3985o681. Email: tatianabatrachenko@gmail.com

**** Ph.D. in Law. Assistant at the Department of Criminal Procedure, Detective and Criminal Investigation of the National University "Odessa Law Academy". ORCID ID: https://orcid.org/oooo-ooo1-57234762. Email: I.l.chuprikova@gmail.com

***** Ph.D. in Law, Head of the Aviation and Water Police Department of the National Police of Ukraine. ORCID ID: https://orcid.org/oooo-0oo1-8838-1837. Email: kryshchenko.ua@gmail.com

Recibido el 14/03/2021

Aceptado el 21/o6/2021 
Keywords: prevention of homicide; premeditated murder; criminal police units; international experience; criminal sciences.

\section{Experiencia internacional en la prevención del homicidio intencional por parte de unidades policiales criminales}

\section{Resumen}

El objetivo del artículo es analizar la experiencia internacional de la prevención operativa e investigativa de los homicidios intencionales por parte de las unidades de la policía criminal, así como la legislación que prevé el desarrollo de un sistema eficaz para la prevención de los homicidios intencionales en Ucrania. El tema de la investigación es la experiencia extranjera de prevención operativa y de búsqueda de homicidios intencionales por parte de unidades policiales criminales. La metodología de investigación incluye métodos generales y específicos de la ciencia jurídica: dialéctica, abstracción científica, métodos de análisis de sistemas, formales y dogmáticos, sistémicos y estructurales, históricos y comparativos, lógicos. Se consideran diversos programas de prevención de homicidios intencionales, que actualmente se encuentran operando en diferentes países del mundo. Se analiza la experiencia internacional positiva de prevención operativa e investigativa de homicidios intencionales, que puede convertirse en la base para el desarrollo de la legislación pertinente de Ucrania en esta área. Se concluye que la realización de un análisis comparativo de la prevención de homicidios intencionales y diversos países es la base para el desarrollo de las áreas más prometedoras para mejorar la legislación interna en esta materia.

Keywords: prevención de homicidio; asesinato premeditado; unidades de policía criminal; experiencia internacional; ciencias penales.

\section{Introduction}

The experience of foreign countries in implementing the strategy of crime control is valuable not only for the theory, but also for the practice of crime prevention in Ukraine. Our state is currently in a state of deep political, economic, and social crisis. The activity of criminal justice bodies is unbalanced. The judiciary and law enforcement agencies are being reforming and therefore qualitative organizational and managerial 
Yevhen Khyzhniak, Volodymyr Kapustnyk, Tetiana Batrachenko, Iryna Chuprikova y Artem Kryshchenko

transformations are taking place. Several new criminal prosecution bodies are being established, namely: the National Police of Ukraine, the National Anti-Corruption Bureau of Ukraine, the State Bureau of Investigation, the National Agency for Corruption Prevention, the Specialized AntiCorruption Prosecutor's Office, etc. In this regard, the study of modern progressive foreign experience in crime prevention with the participation of specialized State institutions deserves special attention.

Accordingly, criminal activity is progressing faster than science, which is designed to counter it. Murders disguised as missing are widespread now. Many of these crimes are linked to the activities of organized criminal groups, which increasingly result in the disappearance of businessmen, bankers, commercial workers, children, the elderly, homeowners, and others (Pavlenko et al., 2015).

The general methods and typical algorithm of actions of the operational officer should be well-established for application in day-to-day performance. In particular, the Instruction on the organization of interaction of pretrial investigation bodies with other bodies and divisions of the National Police of Ukraine in prevention of criminal offenses, their detection and investigation define typical actions of the members of the investigative task force in case of complaints or reports of criminal offences and responses thereto (Order No. 575).

The institution of development of intelligence and the technology of exposing criminal groups that commit intentional homicides is important at the stage of documenting and ensuring pre-trial investigation. Documentation means a set of operational and investigative actions aimed at identifying and recording factual data that are important for the prevention of crimes and their detection. Documentation in operational and investigative activities is defined as the process of reflecting the factual data obtained as a result of operational and investigative measures (ARI) in official documents. It is a way of reproducing the true picture of the criminal act, finding out the circumstances of criminal events in order to make the correct decision to collect factual data that will help establish the truth.

The content of documentation is achieved through the implementation of operational and investigative measures aimed at identifying crimes that are being prepared or committed, obtaining information about those involved in such activity, circumstances of the offense, as well as specific measures to prevent and detect crimes (Hrebeniuk et al., 2018). Successful process of exposing suspects of the thoroughly prepared crime is carried out thanks to the correctly chosen investigative and operational tactics. The methodology of forensic, operational and investigative tactics is based, among other elements, on the active use of data from psychology, logic, pedagogy, criminal analysis, scientific organization of labor and management science. Operational officers apply the operational combinations when carrying out 
covert actions instructions; for example, the ordered set of interconnected and interdependent tactics. The achievement of the planned outputs is possible only under terms of the professionalism of the operational officer, his (her) personal qualities and impeccable mastery of the psychology of communication with the population.

The urgency of the problem and insufficient development of organizational and legal framework for the prevention of violent crimes have determined the purpose of this study. The increase in the scale of such crimes is the real threat to the security of the State and society, as it strengthens its position in view of the monopolization of many types of illegal activities, the lack of reliable mechanisms to counter it (Sevruk, 2015). In this regard, it is necessary to analyze the existing legal framework of Ukraine, which regulates innovation, in detail, as well as to examine the implementation of effective proposals to change such a base, considering the tasks of modernization of law enforcement and judicial authorities (Yunin et al., 2018). Improving national legislation in the area of criminal liability for violent crimes requires the study of modern foreign criminal legislation, which will help to develop and implement the necessary changes and amendments to the Criminal Code of Ukraine.

\section{Methodology}

Research methods are chosen based on the subject matter and the purpose of the study. The article used general and special methods of legal science, in particular: dialectical method, method of scientific abstraction, methods of system analysis, formal and dogmatic, system and structural, historical and comparative and logical methods.

\section{Literature Review}

The term "crime prevention by operational units of the police" was first introduced into scientific circulation by Samoilov in 1982. Not considering this type of activity of operational units of internal affairs bodies an independent form, he defined it as being regulated at the time by departmental regulation activity to carry out individual preventive measures against persons who can be expected to commit crimes. Subsequently, Samoilov (1982, pp. 14-15) adjusted his approach to the definition of such prevention and stated that it is carried out by operatives not only for individual purposes, as it follows from its definition, but also for general crime prevention. 
Yevhen Khyzhniak, Volodymyr Kapustnyk, Tetiana Batrachenko, Iryna Chuprikova y Artem Kryshchenko

Horiaynov et al., (2004) defines such prevention as a set of measures carried out using the means and methods inherent in the operational units of the police to achieve the goals of prevention. Kozachenko (1992) considers the concept of crime prevention in a slightly different way. In his opinion, prevention is a specialized part of the work of law enforcement agencies with the use of covert forces, means and methods of identifying the causes of crimes and conditions that contribute to their commission, persons who can be expected to commit crimes.

These ideas were later developed by Kondratiev (2004), who noted that in a broad sense, crime prevention is a comprehensive use of operational and investigative forces and means, and in a narrow sense it is the activity of operational units to counteract criminal activity by specific individuals clearly regulated by law and relevant regulations.

According to Moiseiev et al., (2009), crime prevention is a regulated activity of the police, which lies in conducting systematic monitoring of the operational situation to eliminate the causes and prevent the conditions conducive to their commission, to identify persons prone to committing offenses, and exercising preventive influence on them in order to prevent the commission of the planned crimes or those that are being prepared.

Ferguson (2017) believes that criminal analytics currently plays the most important role in the prevention of crimes, including violent ones. Using the analytical product "Palantir", the analysts at Los Angeles Police Department's Real-time Analysis Critical Response (RACR) Division processes information, which is in the police records, from the automated system for reading data, messages received on the line " 911 ", video from public surveillance cameras, etc. Based on this information, the analyst uses mathematical algorithms to make a prediction about the high possibility of committing crimes in particular areas by compiling maps indicating the most criminogenic places. As a rule, such maps are provided to the operational police units and patrol police.

International Association of Criminal Analysts (or IACA, 2014) considers criminal analysis to be a process that uses quantitative and qualitative methods to analyze data that are important to the police units in the field of crime prevention, identification of the offenders, determination of the reasons for the crimes, etc.

Professor Ratcliffe in his work "Intelligence-Led Policing" (2016) proves that preventive policing based on operational data and information should be an approach aimed at ceasing "all crimes, risks and all the damage that can be caused by these crimes".

White et al., (2003) state that homicide prevention is a critical police responsibility and that by employing problem-oriented strategies and garnering citizen involvement, police may be able to effectively reduce the prevalence of such violence. 


\section{Results and Discussion}

The urgency of the study is due to the great importance of solving the problems of cessation of intentional homicides in Ukraine. There has been an increase in crime in general and in particularly serious crimes against the person such as intentional homicide in particular in recent years. Thus, the number of registered homicides in Ukraine has increased by almost $10 \%$ over the last 10 years.

With regard to intentional homicides, the statistics provided by Eurostat indicate that during 2007-2012, the dynamics of this most serious type of crime were positive in the vast majority of European countries. As Maksymovych (2008) correctly pointed out, the criminal legislation of most foreign countries has features due to the specifics of the legal system, the importance of relevant relations to the State, the traditions of establishing mandatory rules of conduct, etc. Thus, it is necessary to generalize foreign experience of operative and search counteraction to murders and to provide offers on its introduction in practical activity of law enforcement agencies of Ukraine.

Some foreign countries advocate the most severe sanctions in the form of the death penalty. But humanity has no right to forget that we live in a civilized society, where depriving a person of the right to life is totally inhumane; besides, the death penalty for serious crimes against humanity and the State can be considered a proven historical means of protecting society against violations of the conditions of its normal existence (Zavorina, 2017).

The United States not only has the most powerful economy or the most powerful army in the world, but also has a high prevalence of serious crimes against life and health. Proof of this is the ranking of the most criminogenic cities in the world, which includes New Orleans and Detroit, in which there are 67 and 46 murders per 100,000 populations, respectively. Despite the fact that the population of this country is about $5 \%$ of the world's population, the number of people sentenced to imprisonment is a quarter of this figure worldwide, not counting the 5 million Americans who are released from probation.

The current crime rates in the United States can be supplemented by official statistics from the Federal Bureau of Investigation (FBI) on so-called index crime (UCR - Uniform Crime Reports), which includes murder, rape, aggravated assault, robbery, burglary, burglary (amount over \$ 50), car theft, arson (Lunieiev, 2011; Dzhuzha, 2012).

Among the 72 programs with a high level of effectiveness, there is a project called the Adolescent Transitions Program, which is designed for adolescents aged $11-17$ with delinquent behavior who abuse alcohol 
Yevhen Khyzhniak, Volodymyr Kapustnyk, Tetiana Batrachenko, Iryna Chuprikova y Artem Kryshchenko

and drugs. The key to the success of this program is that not only the fact that psychologists and psychiatrists take part in its implementation, but also parents and family members of troubled adolescents, as well as their teachers. The aim of the project is to eliminate the shortcomings of juveniles' communication with their parents, teachers and immediate environment, change social orientations, values and misconceptions formed under the influence of criminogenic marginal microenvironment. The means to achieve the goals of the program are family therapy, multilevel psychological courses consisting of motivational interviews, group and individual classes and conversations, during which the behavior of minors is corrected, including by teaching their parents the rules of education, basic approaches encouraging children. The effectiveness of this program has been proven in its repeated study by specialists, so it is implemented in some cities to this day.

Thus, in the United States, the program implementation of scientific ideas of modern American criminologist D. Kennedy, who heads the Center for Crime Prevention and Control, and teaches at the John Jay College of Criminal Justice (New York), is now widespread. The essence of his precautionary criminological theory is embodied in the programs "Operation Ceasefire" and "Drug-market Intervention". They are based on the persuasion of members and leaders of street gangs specializing in violent and drug crime to stop their criminal activities (Kolodiazhnyi, 2017).

The aim of the program is to collect the evidence of the facts of committing various crimes by specific individuals by the police. After the police demonstrate to the criminals all the evidence that proves their guilt, the latter are invited to take part in preventive talks with the representatives of the local community (neighbors, friends, teachers, parents, social workers) in exchange for a guarantee not to arrest them. The implementation of these projects has shown high efficiency, as the murder rate was reduced by $60 \%$, and the overall crime rate almost halved in those cities where they were carried out. These programs were first implemented in 2003 in High Point, North Carolina. After encouraging results, this practice is widespread in almost 100 cities in the United States and even other countries (UK, Australia, Brazil, Colombia, Mexico, some Caribbean countries) (Kolodiazhnyi, 2017).

The theory of Papacristos, a sociologist at Yale University in New Haven, Connecticut, is the well-tested theory of US citizens being more victimized to murder. Based on the study of statistics on crimes related to the use of firearms in Chicago, the scientist substantiated the hypothesis that the potential and increased chances of intentional homicide do not depend on such traditional socio-demographic indicators as age, gender, or level of income, and mostly - the social environment, the fact of communication with a certain category of people. The scientist states that violence can be 
compared to a hem contact pathogen. Like the disease, it spreads according to certain laws. The members of the same social network are more likely to commit the same risky things (carry weapons or commit various crimes), which increases their risk of violent death. The researcher studied police files and data on murders that took place in Chicago during 2006 - 2011 in an area of 6 square miles, as it has the highest number of murders. The results of the study showed that $6 \%$ of the population was involved in $70 \%$ of homicides in one way or another, and almost all of the actors involved in one way, or another dealt with the police or the State health care system. Besides, for this most vulnerable group the probability of homicide is nine times higher than the national average (Kolodiazhnyi, 2017).

At present, the theory of Papacristos is widely used by the Chicago police. According to the crime prevention program, law enforcement officers use the so-called network analysis to identify the 20 residents of the neighborhood who have the highest potential to be the killer or victim of this crime. As part of this program, assistant police officers from the local Chicago population are widely involved, who, instead of the usual arrests and criminal proceedings on suspicion of committing crimes, conduct appropriate preventive talks with the representatives of the risk group. This experience is spreading to other US cities as well (McDonald, 2013).

Crime prevention in the UK is carried out in three main forms: situational, social, prevention with the help of the public. Special prevention is carried out at three levels:

- the primary level of prevention, aimed at eliminating external environmental factors that contribute to the commission of offenses.

- secondary level of prevention, which is aimed to prevent criminalization of potential offenders and related to the impact on vulnerable persons, including children at risk.

- tertiary level of prevention, aimed at preventing recidivism by persons who have already committed offenses.

The secondary level of prevention is called upon to prevent the criminalization of those whose behavior and lifestyle indicate the possibility of committing offenses. In contrast to primary prevention measures, which are general in nature and aimed at eliminating the causes and conditions of offenses, secondary prevention measures are individual in nature and involve the impact on the person, his (her) negative traits that determine illegal behavior. Secondary prevention measures are based on predicting the individual behavior of a person, which lies in studying persons prone to delinquency and the sources of negative impact on them. Specific measures of individual prevention are various school programs of education and control over the behavior of minors "at risk", as well as programs designed to work preventively with their parents. Such programs are implemented 
Yevhen Khyzhniak, Volodymyr Kapustnyk, Tetiana Batrachenko, Iryna Chuprikova y Artem Kryshchenko

638 International experience in preventing intentional homicide by criminal police units

by the joint efforts of the police units, educational institutions, and social services.

The tertiary level of crime prevention aims to prevent recidivism by those who have already committed offenses. Prevention of recidivism is associated with the work of police, judicial, penitentiary measures aimed at the timely identification of perpetrators, bringing them to justice, as well as the use of effective means while serving their sentences. Special role in the prevention of recidivism is given to criminal law measures of influence. In order to prevent recidivism, the measures of increased control over the behavior of convicts are also widely used, as well as programs for their individual rehabilitation (Dzhuzha et al., 2011).

In 2006 in Germany the project called "Jet" was introduced, which is still operating nowadays. The essence of this program lies in the reactive, rapid response of various actors of preventive activity to violent crime in the juvenile environment. In particular, the Heilbronn Police Department decided to change the local law enforcement concept to limit the exclusive response to juvenile violence already committed, while increasing the presence of police officers and volunteers in public places, especially on weekends and holidays.

The "reactivity" of this project is due to the speed of the criminal prosecution of violent criminals, as well as a broad information campaign of local media, which informs the public about the constant presence of police and volunteers on the streets not only during mass entertainment events, but also in other days. Besides, the key to the effectiveness of this program is to apply preventive measures to the leaders of informal groups of adolescents, who are most often involved in mass riots (European Crime Prevention Network, 2014).

Major crimes in Japan have shown a steady downward trend in recent years. Thus, the number of intentional homicides detected by the police decreased by $88 \%$, burglary - by $310 \%$, robbery - by $219 \%$, theft of vehicles - by $254 \%$, rape - by $175 \%$. The decrease in the registration of the main types of general criminal offenses by the Japanese police indicates a general decrease in the crime rate in this country.

The high efficiency of the Japanese police can also be attributed to the fact that in most cases, police officers live in booths (posts) in their separate rooms with their families. Due to the constant presence of the police officer at his (her) place of work, which coincides with the place of actual residence, close cooperation is achieved with the residents of the local community. The latter do not treat the policeman as the representative of the authorities, but, first of all, as a neighbor. In addition, high confidence in the police in this country is also achieved through the performance of their duties without firearms. The main function of the Japanese police at the local 
level is not law enforcement, but social services. This means that Japanese law enforcement officers are in constant contact with the residents of a particular locality, and the police help to solve social, domestic and other problems that citizens face every day. For the modern policeman of this State, it is the norm to treat the visitors of the police booth (post) with tea or to provide the neighbors with an umbrella. It should be noted that the Japanese model of an extensive system of police stations at the local level has found support in many countries: Singapore, Indonesia, Costa Rica, Guatemala, Honduras, El Salvador, Nicaragua. For example, more than 200 police stations were created in the Brazilian metropolis of Sao Paulo before the final of the 2014 FIFA World Cup in 2014, following the example of Japanese police booths. This measure, along with other crime prevention measures, has significantly reduced homicide rates in Sao Paulo (Wood, 2015).

\section{Conclusion}

At first glance, the detection and investigation of intentional homicides should not pose a problem. This type of crime, unfortunately, has been committed and continues to be committed throughout human history. However, new ways of committing and masking murders are emerging, which requires updated techniques and tactics to solve them (Khyzhniak et al., 2021). Having analyzed foreign experience in the area of crime prevention, Zavorina (2017) proposed to apply the following measures in the activities of the National Police of Ukraine: 1) creation of a Standard Model for Combating Crime at the Regional Level, which will include both general methodological issues and the list of necessary measures classified into sections and subdivisions for certain areas of police prevention ; 2) creation of the coordinating body (council) for crime prevention at the level of regional departments of the National Police. It should be entrusted with the functions of developing policies in the area of regional crime prevention; planning activities in this area; informing the population on the measures of crime prevention, etc.; 3) adoption of short-term regional programs (for $1-2$ years) to prevent crime. This program should reflect the goals, nature, means, methods and general direction of crime prevention activities at the regional level. The system of measures in this area should also be fixed, the basic levels and directions of activity in the area of crime prevention should be specified.

Operational and preventive measures as the main direction in the fight against premeditated murder should not be limited just to identifying the causes of these crimes and their elimination, but also provide for such measures as creating an atmosphere of intolerance to the violations of the norms and rules of public life, involvement of the population in 
Yevhen Khyzhniak, Volodymyr Kapustnyk, Tetiana Batrachenko, Iryna Chuprikova y Artem Kryshchenko

640

International experience in preventing intentional homicide by criminal police units

combating crimes, the imposition of equitable punishment for the crime committed, the proper organization of its serving. It should be noted that the implementation of these measures in the practice of criminal police units will undoubtedly positively contribute to the fight against intentional homicides. State and legal mechanisms should guarantee the safety of each member of the society, as the safety of the individual depends on the mutual social well-being, which determines the main task of the law enforcement system.

\section{Bibliographical References}

DZHUZHA, Oleksandr. 2012. "Basic indicators of crime: international and domestic experience" In: Bulletin of the Supreme Court of Ukraine. No. 1, pp. 37-42.

DZHUZHA Oleksandr; VASYLEVYCH, Volodymyr; HIDA, Oleksandr. 2011. Crime prevention: a textbook. Attika. Kyiv, Ukraine.

EUROPEAN CRIME PREVENTION NETWORK (EUCPN). 2014. Project Description “JET". Available online. In: https://eucpn.org/sites/default/ files/document/files/gp_de_jet.pdf. Date of consultation: 09/11/2020.

FERGUSON, Andrew G. 2017. The rise of big data Policing: Surveillance, Race, and the Future of Law Enforcement. New York University Press. New York. Available online. In: https://doi.org/10.2307/j.ctt1pwtb27. Date of consultation: 09/09/2020.

HORIAYNOV, Konstantyn; OVCHYNSKYI, Vladymyr; SINILOV, Hryhoryi; SHUMILOV, Alexandr. 2004. Operational and search activity: textbook. $2^{\text {nd }}$ Edition. Infra. Moskow, Russia.

HREBENIUK, Maksym; TUPELIAK, Ivan; KOMARNYTSKA, Oksana. 2018. Prevention of typical mistakes in documenting the activities of organized criminal groups: a handbook. National Security and Defense Council of Ukraine, Prosecutor General's Office, National Academy of Prosecutor's Office of Ukraine. Kyiv, Ukraine.

INTERNATIONAL ASSOCIATION OF CRIME ANALYSTS (IACA). 2014. Definition and Types of Crime Analysis Standards, Methods, \& Technology (SMT) Committee White Paper 2014-02 October 2014. Available online. In: https://silo.tips/download/definition-and-typesof-crime-analysis. Consultation date: 14/12/2020.

KHYZHNIAK, Yevhen; KHANKEVYCH, Andrii; NAZARENKO, Ihor; PLESKACH, Oleh; TRETIAK, Oleksandr. 2021. "Model of Operational 
Search Prediction of Intentional Homicide by Criminal Police". In: Amazonia Investiga. Vol. 10, No. 40, pp. 37 - 44. Available online. In: https://doi.org/10.34069/AI/2021.40.04.4. https://amazoniainvestiga. info/index.php/amazonia/article/view/1595/1638. Consultation date: 14/12/2020.

KOLODIAZHNYI, Maksym. 2017. Modern foreign experience of public influence on crime: a monograph. Pravo. Kharkiv, Ukraine.

KONDRATIEV, Yaroslav. 2004. Theoretical, legal, and operational and tactical principles of crime prevention by operational units of the criminal police: monograph. National Aacademy of Internal Affairs of Ukraine. Kyiv, Ukraine.

KOZACHENKO, Ivan. 1992. Legal and organizational-tactical bases for operational and search prevention of crimes. Doctoral Dissertation. All-Russian Research Institute of the Ministry of Internal Affairs of the Russian Federation. Moscow, Russia.

ORDER No. 575. On the adoption of the Instruction on the organization of interaction of pre-trial investigation bodies with other bodies and divisions of the National Police of Ukraine in prevention of criminal offenses, their detection and investigation. Official Gazette of the Verkhovna Rada of Ukraine, Kyiv, Ukraine, July 07, 2017. Available online. In: https://zakon.rada.gov.ua/laws/show/z0937-17\#Text. Consultation date: $14 / 12 / 2020$.

LUNIEIEV, Viktor. 2011. Course of the world and Russian criminology: textbook in 2 Volumes. Vol. 1: General Part. Yurait. Moscow, Russia.

MAKSYMOVYCH, Roman. 2008. The concept of an official in the criminal law of Ukraine: a monograph. Lviv State University of Internal Affairs. Lviv, Ukraine.

MCDONALD, Amy A. 2013. Study finds social networks are key to city violence. Available online. In: Yale News https://news.yale.edu/2013/11/14/ study-finds-social-networks-are-key-city-violence. Consultation date: 14/12/2020.

MOISEIEV, Yevhen; DZHUZHA, Oleksandr; NYKYFORCHUK, Dmytro. 2009. Operational and search activity: textbook. Legal Unity. Kyiv, Ukraine.

PAVLENKO, Serhii; SEVRUK, Volodymyr; ISHCHUK, Dmytro. 2015. Investigation of murders related to the disappearance of a person: problematic issues and areas for improvement. Available online. In: http://elar.naiau.kiev.ua/bitstream/123456789/8163/1/\%do\%9f\% do\%ao\%do\%90\%do\%92\%do\%9e\%do\%92\%do\%86\%20\%do\%ao\%do 
Yevhen Khyzhniak, Volodymyr Kapustnyk, Tetiana Batrachenko, Iryna Chuprikova y Artem Kryshchenko

642 International experience in preventing intentional homicide by criminal police units

\%95\%do\%a4\%do\%9e\%do\%ao\%do\%9c\%do\%98\%20\%do\%a7\%201_ p255-257.pdf. Consultation date: 14/12/2020.

RATCLIFFE, Jerry H. 2016. Intelligence-Led Policing. 2nd Edition. Routledge. New York, USA.

SAMOILOV, Vladimir. 1982. Some aspects of the characteristics of operational and search activities as a process of cognition. Issues of improving the operational work of law enforcement agencies. Omsk Militia Higher School of the Ministry of Internal Affairs of the USSR. Omsk, URSS.

SEVRUK, Volodymyr. 2015. "Measures to counteract transnational drug trafficking committed by the representatives of certain ethnic groups" In: Legal Journal of the National Academy of Internal Affairs, No. 2, pp. 193-205.

WHITE, Michael D; FYFE, James J; CAMPBELL, Suzanne P; GOLDKAMP, John S. 2003. "The Police Role in Preventing Homicide: Considering the Impact of Problem-Oriented Policing on The Prevalence of Murder" In: Journal of Research in Crime and Delinquency. Vol. 40, No. 2, pp. 194225. Available online. In: https://doi.org/10.1177/o022427803251126. Consultation date: 14/12/2020.

WOOD, Alan. 2015. Japan May Offer a Way Forward for Better Community Policing in Bibb County. In: Macon monitor. Available online. In: http://maconmonitor.com/2015/03/26/japanese-kobans-communitypolicing. Consultation date: 14/12/2020.

YUNIN, Oleksandr; SEVRUK, Volodymyr; PAVLENKO, Serhii. 2018. "Priorities of economic development of Ukraine in the context of European integration" In: Baltic Journal of Economic Studies. Vol, 4, No. 3, pp. 358-365.

ZAVORINA, Olena. 2017. "International experience of countering units of the national police with murders committed by minors" In: Forum Prava. No. 5, pp. 148-156. Available online. In: http://doi.org/10.5281/ zenodo.1194880 https://zenodo.org/record/1194880\#.YIkKC9UzaUl. Consultation date: 14/12/2020. 
Vol. 39 N $^{\circ} 69$

Esta revista fue editada en formato digital y publicada en julio de 2021, por el Fondo Editorial Serbiluz, Universidad del Zulia. Maracaibo-Venezuela 